\title{
Article
}

\section{Teaching in Hospitals and Healthcare Resorts: A Qualitative Study of Teachers' Needs}

\author{
Agnieszka Małkowska-Szkutnik ${ }^{1}$, Aleksandra Berkowska ${ }^{1}$, Maja Gajda ${ }^{1, *}$ and Dorota Kleszczewska ${ }^{2}$ (D) \\ 1 Department of Biomedical Foundations of Development and Sexology, Faculty of Education, \\ Warsaw University, 00-561 Warsaw, Poland; amalkowska@uw.edu.pl (A.M.-S.); \\ a.berkowska@uw.edu.pl (A.B.) \\ 2 Institute of Mother and Child Foundation, 01-211 Warsaw, Poland; dorota.kleszczewska@imid.med.pl \\ * Correspondence: maja8gajda@gmail.com
}

check for updates

Citation: Małkowska-Szkutnik, A.; Berkowska, A.; Gajda, M.; Kleszczewska, D. Teaching in Hospitals and Healthcare Resorts: A Qualitative Study of Teachers' Needs. Educ. Sci. 2021, 11, 311. https:// doi.org/10.3390/educsci11070311

Academic Editor: Eila Jeronen

Received: 26 May 2021

Accepted: 18 June 2021

Published: 23 June 2021

Publisher's Note: MDPI stays neutral with regard to jurisdictional claims in published maps and institutional affiliations.

Copyright: (c) 2021 by the authors. Licensee MDPI, Basel, Switzerland. This article is an open access article distributed under the terms and conditions of the Creative Commons Attribution (CC BY) license (https:// creativecommons.org/licenses/by/ $4.0 /)$.

\begin{abstract}
The daily functioning of children who suffer from chronic conditions may be limited by the disease and by hospitalization. Hospital schools have an important role in counterbalancing those negative effects. The aim of the study was to define hospital schools' teachers' needs. The data from qualitative research conducted on 21 Polish hospital school teachers was included in the analysis. A semi-structured interview method was chosen. Researchers played an active role as moderators. Thirty-four descriptive codes were assigned to the main five areas of needs related to: work conditions, the character of work, psychological support, self-fulfillment, and social relations. The results showed that the teachers were concerned about hospital school marginalization, they received no mental health support, and felt that the extent of their role was underestimated by medical staff. The lack of recognition is likely to make teachers feel frustrated, and demotivated. By learning more about what hospital teachers think of their work, it is possible to create recommendations for changes. There seems to be a need to raise awareness of the importance of schools in health care institutions.
\end{abstract}

Keywords: hospital schools; healthcare resorts; teachers; teaching; needs; qualitative study

\section{Introduction}

Hospital schools offer education to hospitalized children in hospital wards, which is particularly important for children and adolescents with chronic diseases, who require long or frequent hospital stays [1]. According to the Health Status of Population in Poland report, more than $21 \%$ of children aged 7-16 have chronic medical conditions [2]. The number of such children is similar in other European countries and the US and has been estimated to affect around $10-30 \%$ of the child population, depending on the adopted criteria [3-6]. The problem of chronic diseases is prevalent and the number of children who suffer from this type of medical condition has steadily been increasing for some time [6-8]. Among the causes are poor diet and lack of physical activity, as well as notable medical advancements that have led to an increase in survival rates for children with chronic conditions $[7,9]$.

The daily functioning of children with chronic conditions may be limited by the healthrelated consequences of the disease, its treatment, and by hospitalization and medical procedures [10-12]. As a result of these limitations, children are often unable to attend schools regularly [13-15], and thus they should have access to alternative education [16,17]. Otherwise, they may be at risk of social, emotional, and academic setbacks arising from hospitalization-related school absenteeism [18-28].

Hospitalization may have a negative impact on the way children function [28-30] and hospital schools are important in counterbalancing some of these negative effects [30]. Recurrent or long hospital stays result in less time spent in the classroom, which may affect students' relationships with peers $[1,22,31]$, their school success and school engagement [32]. Furthermore, children and adolescents may face some difficulties when they 
return to regular schools. They may experience attention and concentration problems and attempt to fulfill their primary socialization needs before completing learning tasks [33]. Hospitalization also puts children and adolescents at risk of experiencing anxiety caused by separation from the family, change of the environment, being diagnosed or undergoing treatment [34-37]. However, the research has shown they experience less stress during hospitalization when teachers are around [32,38]. Moreover, teachers help students stay engaged in social interactions by organizing various group activities, and keep them motivated during individual lessons. Teachers' presence at pediatric wards not only helps children catch up with school material, but also proves to be important for the students' wellbeing [39-41].

Hospital teachers are central to the continuity of education and support provided to children, and the quality of teachers' work is connected, amongst other things, with their job satisfaction [42-45]. In general, teachers, to work effectively and perform well, need to feel that their work is important [45]. When their job-related needs are satisfied, they are more likely to be motivated [46-49]. Merike Sisask et al. showed that teachers who perceive the school environment as good and feel valued by others, are more eager to help students with mental health problems [48].

There has been a considerable amount of easily accessible research on mainstream teachers' needs. However, a review of the literature suggests that research on hospital teachers' needs is scarce. To ensure that teachers' work quality at hospital schools is optimal for the child's well-being, it is necessary to diagnose hospital teachers' needs and address them adequately.

In the next part of the article, the background, and characteristics of hospital education are provided. The presented information may be useful in allowing one to glean a deeper understanding of hospital teachers' problems and needs.

\subsection{Characteristic of Hospital Schools}

The history of hospital pedagogy had not been well documented until modern times. Although there were some accounts of hospital teaching practices in the 17th and 19th centuries in Europe [50], one of the better-known precursors of hospital education is Sir William Purdie Treloar, who opened a school and hospital for children with non-pulmonary tuberculosis in the United Kingdom at the beginning of the 20th century [51]. However, it was not until the early 1980s that hospital schools were established officially and regulated by national laws in most European countries, among others in Germany, Poland, Spain, and Italy [52]. At that time, national governments started taking an interest in the need to ensure appropriate special education in a hospital setting.

Hospital schools in Poland are organized in accordance with the Regulations of the Minister of National Education. The quality of education is under the supervision of the Local Education Authority, subordinate to national government administration. However, it is the local government that directly supervises how schools function in general and provides the funding [53-56].

Apart from schools established in hospitals, in some countries, there are also schools located at health care resorts (sanatoriums). Such resorts are popular in many Eastern European countries [57], and can also be found in Western Europe, for example in Austria and Germany. Health care resorts offer a combination of recreational and medical services such as treatment of upper respiratory tract diseases, dysfunctions of limbs or the nervous system. The treatment is based on the use of physiotherapy, balneology, medical hydrology, and climatology [58]. Young patients invariably spend several weeks there and attend special school during that time.

There are differences across countries regarding the organization of hospital schools due to national regulations [52]. In Poland, hospital schools are autonomous entities with their own management structures and employees. However, in other countries such as Italy, teachers are being designated from mainstream schools to work in hospital schools [59]. In Germany, for example, there is a mixed system, which means that in some states, hospital 
schools are autonomous whilst in others, teachers are being seconded from mainstream to hospital schools [60].

Although some differences in the organization of schools exist, there are also many similarities. Usually, teaching in hospital school is planned and carried out in consultation with the head of the hospital ward or the attending physician, who may decide to halt classes due to the poor health condition of the patient [61]. Hospital teachers mostly follow the same core curriculum that is used in mainstream schools [52,62], which is recommended by the Hospital Organization of Pedagogues in Europe-HOPE [52]. Hospital teachers organize various activities and teach students from preschool, elementary, and sometimes also secondary school level $[17,52]$. However, in countries such as Poland and Greece secondary education is almost non-existent in hospital schools [52], whereas, for example, in the United Kingdom it is widely available for hospitalized adolescents [63].

\subsection{The Characteristics of Work in the Hospital Setting and the Role of a Hospital Teacher}

Hospital teachers' qualification requirements differ across countries. For example, in Germany, Poland, and the United Kingdom, subject teachers and educators who work with students in the hospital setting are required to have appropriate qualifications in Special Needs Education [60-62]. In comparison, in Hungary, Bulgaria, Bosnia and Herzegovina, Greece, or Italy, there are no national legal regulations as to teachers' qualifications and training $[52,59,64,65]$. Educators usually organize only extracurricular activities. Their role is important because children perceive hospitals not only as places of treatment but also as a social space that should offer recreational activities [66,67]. Educators also take care of students' well-being and help them develop passions. In the United Kingdom, there is also a profession of hospital play therapist as an alternative role in education. A hospital play therapist is qualified to work with students in order "to minimize the trauma [they] may experience from being ill and separated from parents while undergoing unpleasant medical procedures" [62].

Children and adolescents' social and emotional wellbeing at school is described as a top priority by the World Health Organization [68], and many countries follow this idea in national documents and curricula. However, the school pressure on students with chronic conditions is high. They are graded equally with their peers and have to take external standardized examinations, which may be an additional stressor (Brown, B. Negative Effects of Standardized Testing). In general, they are not eligible for special consideration during exams [63]. In addition, hospital teachers are usually required to grade students' performance. However, in the Czech Republic, they can do it only if "the child has spent at least three months in the hospital" [64], whereas in Poland, for example, teachers can assess a student's performance at any moment of their hospital stay.

Hospital school teachers fulfill many roles in the performance of their work. As didactic teachers and educators, they perform professional tasks crucial to students' educational and personal growth. They support students' emotional well-being [40], and sometimes, are also a source of support for parents and other teachers $[59,69]$. Their presence gives students a sense of continuity and purpose in life [70,71], and by organizing group activities, they also facilitate socialization processes in students [41]. All in all, hospital teachers' work is important to students' educational, emotional, and social development [72-74].

\subsection{Purpose of the Study}

Although the quality of special education in a hospital school is important for children and adolescents, research on this subject seems to be insufficient $[40,75,76]$. As mentioned before, when teachers have a high level of job satisfaction, they tend to be more motivated and supportive towards their students. Therefore, it is important to explore hospital teachers' needs satisfaction, and perceptions of their work environment.

The main aim of the study was to analyze hospital teachers' needs. An additional aim was to define the characteristics of hospital teachers' work environment. The main research question was: What needs do hospital teachers have related to their work? 


\section{Materials and Methods}

\subsection{Introduction}

The following article presents the results of qualitative research conducted on Polish hospital school teachers as part of an international project Back to School (BTS Project), financed by Erasmus+ and carried out in collaboration among three countries, namely, Poland, Portugal, and Italy. The institution coordinating the cooperation was the Foundation of the Institute of Mother and Child (Poland). The main aim of the BTS Project was to learn more about the widely defined needs of teachers who worked in children's hospitals and healthcare resorts, using quantitative and qualitative studies. Based on the results, guidebooks and innovative materials for teachers, parents, and students with special educational needs (i.e., chronic diseases) will be created. The BTS Project received a positive opinion from the Bioethical Committee of the Institute of Mother and Child (number 23/2020, 21 May 2020).

\subsection{Participants' Characteristics}

Taking into account the main goal of the research, the following study inclusion criteria were developed: (1) being an active teacher at a hospital school; (2) having at least one year of work experience in a hospital school; (3) having at least a contractual teacher's degree of promotion.

Hospital teachers (21 persons) took part in the interviews, including three sanatorium school teachers. At the time of conducting the interviews, the participants were employed in six hospital schools including two sanatorium schools. Only one person was employed on a specified time contract, and the remaining 20 were on permanent employment contracts. Eighteen participants worked in schools located in cities (100,000+ inhabitants), two participants worked in towns and one teacher worked in a school located in a village. The sample consisted of 2 men and 19 women. The participants ranged from 28 to 56 years of age and held a Master's degree, which is required by Polish legislation.

The participants can be characterized according to their professional advancement. Every level of teachers' career development ends with an official examination. In the study, there were two contractual teachers (at least 1 year of career development), two appointed teachers (at least 6 years), 17 chartered (certified) teachers (at least 10 years; the highest attainable rank).

The interviewees had from 2 to 35 years of experience. However, only one person had 2 years of experience, and the remaining 20 ranged from 8 to 35 years. The participants worked with students at all educational levels, from preschool to secondary school. There were subject teachers and educators. Table 1 shows the professional profile of the participants (Table 1).

Table 1. The professional profile of the participants.

\begin{tabular}{|c|c|c|c|c|}
\hline Teacher & Gender & $\begin{array}{c}\text { Degree of Professional } \\
\text { Advancement }\end{array}$ & $\begin{array}{l}\text { Experience as a Hospital } \\
\text { School Teacher in Years }\end{array}$ & Professional Roles \\
\hline $\mathrm{T} 1$ & $\mathrm{~F}$ & appointed & 9 & Teacher (English, French, art, and music) \\
\hline $\mathrm{T} 2$ & $\mathrm{~F}$ & chartered & 12 & Preschool teacher and educator \\
\hline T3 & $\mathrm{F}$ & chartered & 15 & Math teacher \\
\hline $\mathrm{T} 4$ & $\mathrm{~F}$ & chartered & 16 & Educator \\
\hline T5 & M & appointed & 8 & $\begin{array}{l}\text { Early education language teacher and } \\
\text { educator }\end{array}$ \\
\hline T6 & $\mathrm{F}$ & chartered & 19 & English language teacher \\
\hline $\mathrm{T} 7$ & $\mathrm{~F}$ & chartered & 27 & $\begin{array}{l}\text { Religion teacher and early education } \\
\text { teacher }\end{array}$ \\
\hline $\mathrm{T} 8$ & $\mathrm{~F}$ & chartered & 8 & Preschool teacher \\
\hline T9 & $\mathrm{F}$ & chartered & 17 & German language teacher \\
\hline
\end{tabular}


Table 1. Cont.

\begin{tabular}{|c|c|c|c|c|}
\hline Teacher & Gender & $\begin{array}{c}\text { Degree of Professional } \\
\text { Advancement }\end{array}$ & $\begin{array}{l}\text { Experience as a Hospital } \\
\text { School Teacher in Years }\end{array}$ & Professional Roles \\
\hline $\mathrm{T} 10$ & $\mathrm{~F}$ & chartered & 8 & Polish language and history teacher \\
\hline $\mathrm{T} 11$ & $\mathrm{~F}$ & chartered & 35 & Preschool teacher \\
\hline T12 & $\mathrm{F}$ & chartered & 27 & Polish language teacher \\
\hline T13 & $\mathrm{F}$ & chartered & 29 & Educator \\
\hline T14 & $\mathrm{F}$ & contractual & 2 & Educator \\
\hline T15 & M & chartered & 13 & Educator \\
\hline T16 & $\mathrm{F}$ & chartered & 15 & Educator \\
\hline T17 & $\mathrm{F}$ & chartered & 15 & $\begin{array}{c}\text { Early education language teacher and } \\
\text { educator }\end{array}$ \\
\hline T18 & $\mathrm{F}$ & chartered & 27 & Math teacher \\
\hline T19 & $\mathrm{F}$ & chartered & 26 & Educator \\
\hline $\mathrm{T} 20$ & $\mathrm{~F}$ & contractual & 5 & Educator \\
\hline $\mathrm{T} 21$ & $\mathrm{~F}$ & chartered & 34 & Preschool and early education teacher \\
\hline
\end{tabular}

\subsection{Instruments}

A semi-structured interview method was chosen due to the aim of the study. The researchers wanted to get detailed descriptions of hospital teacher's needs. The semistructured interviews had no restrictions as to the form or order of questions, which enabled the exploration of unexpected topics and asking of follow-up questions [77,78]. Such freedom of expression during interviews facilitated a multifaceted understanding of interviewees' perceptions.

In the first phase of the research, a short anonymous questionnaire with sociodemographic data was prepared. There were questions regarding age, gender, qualifications, location of the hospital school, professional advancement, work experience as a teacher and as a hospital teacher, and the teacher's role at the school.

In the second phase, topics related to the purpose of the study were pre-planned. They were raised with teachers and the first interview was a pilot interview. Then, the final form of interview discussion points was agreed upon. The pre-determined questions corresponded with the research questions.

Apart from questions regarding needs (i.e., what are the most difficult aspects of your job? Why? What could help you overcome those difficulties? What is important in your work? What could be improved?), there were also questions concerning the organization of hospital education during the COVID-19 pandemic. However, the results of this part of the interview will be presented in a separate publication.

\subsection{Data Collection}

During this stage of qualitative research, three group interviews were conducted. One of them took place on the 8 June 2020 (four participants), the remaining two on 17 November 2020 (seven and ten participants, respectively). Each interview lasted approximately one hour.

Due to the COVID-19 pandemic, the interviews were conducted online. Participants took part in the interviews from home or work. Google Meet was used to conduct the interviews and record the audio.

The pre-prepared interview scenario was used. The interviews took into account the guidelines of the Data Protection Officer (DPO) of the University of Warsaw. Two researchers were present at each of the interviews. One acted as a moderator, the other oversaw as technical support and assistance. 
In line with the plan, the moderators opened the interviews with an introduction, and, following the procedures imposed by the DPO, obtained informed consent from the participants. The form of consent was displayed on the shared screen and read aloud. The teachers were also informed that the recordings would be used for academic purposes only. Next, the moderator described the aim of the study, and planned outputs of the Back to School project. Due to the online form of the interviews and their later transcription, rules were brought forward to ensure that interlocutors would not interrupt each other (briefing) [79]. After that, the participants answered the questions. The final question was a form of summarizing the interview (debriefing) [79].

\subsection{Organization of the Study}

Originally, it was planned to send invitations for participation in the study to all hospital schools included in the official list of schools in Poland [80]. However, due to the COVID-19 pandemic, some hospital schools were closed at that time, and others worked according to various restrictions. Because of the circumstances, only 48 hospital schools could be contacted by phone. As a result, a group of 21 teachers expressed their readiness to answer questions. All 21 volunteers met the criteria of study inclusion. Before the interviews, all participants mailed filled in questionnaires with the basic socio-demographic data, which was mentioned in the instruments section of the article.

Although some hospital schools were closed at the time of the research, teachers kept working remotely or used blended/hybrid teaching. At the beginning of the interviews, the respondents were asked to think about the pre-pandemic time, when they answered questions about the needs related to their work in the hospital.

\subsection{Methods of Analysis}

The data obtained in the study was analyzed with descriptive analysis and a twostep coding procedure [81]. The interviews were transcribed and anonymous symbols were given to every participant, which assured the clarity of presented citations and the appropriate analysis of the frequency of statements. Firstly, the main areas related to the research questions were identified. Secondly, the detailed descriptive codes were assigned to them by two independent researchers. Atlas, a program assisting qualitative data analysis, was used in that stage. The codes proved to be consistent. However, there were some slight differences in the nomenclature. After discussion, uniform code labels were created. The analysis was done without prior preparation of a list of codes. This method allowed openness to unexpected topics raised by the participants. It is also in alignment with the characteristics of qualitative studies, which should not try to predict outcomes a priori [81].

\section{Results}

During the first stage of data analysis, the following main areas related to teachers' needs were defined: (1) material needs and needs for systemic change; (2) needs connected with the character of work; (3) psychological needs; (4) self-fulfillment needs resulting from job satisfaction; (5) needs connected with social relationships. Detailed codes are defined for each category.

Table 2 shows the frequency of codes that are grouped under the main categories and ranked from the most to the least frequent (Table 2). In total, 34 codes were defined for the five main areas. The frequencies are as follows: (1) material needs and needs for systemic change $\mathrm{F}=42$; (2) needs connected with the character of work F = 38; (3) psychological needs $\mathrm{F}=14$; (4) self-fulfillment needs resulting from job satisfaction $\mathrm{F}=40$; (5) needs connected with social relations $\mathrm{F}=89$. 
Table 2. General and detailed themes (frequency).

\begin{tabular}{|c|c|c|}
\hline General Theme & Detailed Theme & Frequency \\
\hline \multirow{5}{*}{$\begin{array}{l}\text { 1. Material needs and } \\
\text { needs for systemic } \\
\text { change }\end{array}$} & $\begin{array}{l}\text { Greater awareness of hospital schools' legal regulations: implementation of a } \\
\text { curriculum, internal evaluation system, personal data collection }\end{array}$ & 12 \\
\hline & $\begin{array}{l}\text { Difficult working conditions (no dedicated school rooms where lessons could be } \\
\text { taught, no employees' rooms) }\end{array}$ & 9 \\
\hline & Validation of the status of a hospital school & 9 \\
\hline & The need to educate teachers from mainstream schools about chronic diseases & 9 \\
\hline & The need to take into account the specificity of the school in law regulations & 3 \\
\hline \multirow{7}{*}{$\begin{array}{l}\text { 2. Needs connected with } \\
\text { the character of work }\end{array}$} & Individualized work adapted to the student's health condition & 13 \\
\hline & The therapeutic dimension of work & 7 \\
\hline & Normalizing function of the hospital school & 6 \\
\hline & Flexibility and non-standard working hours & 4 \\
\hline & Work in various hospital wards & 4 \\
\hline & Interrupted lessons & 2 \\
\hline & Combined classes & 2 \\
\hline \multirow{3}{*}{ 3. Psychological needs } & Coping with the death of a student & 6 \\
\hline & Dealing with stress and strong emotions (the need for training) & 4 \\
\hline & Need for emotional support & 4 \\
\hline \multirow{6}{*}{$\begin{array}{l}\text { 4. Self-fulfillment needs } \\
\text { resulting from job } \\
\text { satisfaction }\end{array}$} & Good contact with students & 13 \\
\hline & Student's smile and joy & 9 \\
\hline & Student's engagement in school & 6 \\
\hline & Student's educational progress & 5 \\
\hline & Parents' satisfaction and gratitude & 4 \\
\hline & Student's signs of gratitude & 3 \\
\hline \multirow{18}{*}{$\begin{array}{l}\text { 5. Needs connected with } \\
\text { social relationships }\end{array}$} & 1. Relationships with the student: & \\
\hline & Supporting the student's well-being & 7 \\
\hline & Improving contact with the student & 6 \\
\hline & Developing students' passion & 3 \\
\hline & Supporting students in understanding the disease & 3 \\
\hline & 2. Relationships with parents: & \\
\hline & Cooperation with parents & 12 \\
\hline & Social support for parents & 7 \\
\hline & 3. Relationships with hospital staff (doctors, nurses) & \\
\hline & The need for space sharing & 11 \\
\hline & $\begin{array}{l}\text { The need for recognition of hospital teachers' role in taking care of children's } \\
\text { well-being }\end{array}$ & 4 \\
\hline & 4. Relationships with mainstream school teachers: & \\
\hline & Need for mainstream school teachers to recognize grades given at the hospital & 14 \\
\hline & Collaboration between schools & 10 \\
\hline & The need to ensure that peers from the class have contact with the hospitalized child & 4 \\
\hline & The need to increase mainstream school teachers' interest in the hospitalized student & 3 \\
\hline & Educating peers about the disease & 3 \\
\hline & Exchange of information between schools about school material they need to work on & 2 \\
\hline
\end{tabular}

\subsection{Material Needs and Needs for Systemic Change}

The first area of needs is focused around hospital school regulations: (a) implementation of curricula, internal evaluation system, and personal data collection ( $\mathrm{F}=12)$; (b) validation of the status of a hospital school ( $F=9$ ); (c) the need to take into account the characteristics of hospital school in law regulations $(\mathrm{F}=3)$.

All law regulations basically apply to mainstream schools and we have to adapt to those regulations. 
It would be good if there were some knowledgeable, separate laws regulating the workflow of teachers in healthcare resorts.

The participants point to the lack of systemic and legislative changes that could improve the functioning of hospital schools.

The next area of needs is connected with work conditions $(F=9)$. Many respondents report that they do not have sufficient on-site facilities. Because of the lack of dedicated school rooms, teachers have to teach in recreational rooms where other patients spend their free time, or in waiting rooms for parents. Several teachers also admit they do not have teachers' rooms to store educational aids. The described difficulties are reflected in the following statements:

It is difficult to store educational aids because in our hospital we haven't had a permanent teachers' room for several years now. We constantly change rooms and need to carry all those aids around. It's not easy for me.

We try to find some space for ourselves. However, you know, medical science is still developing, and doctors need more and more room. We feel pushed around a little bit somewhere. It's especially hard for subject teachers.

I just wish there was a place where a child could focus only on the lesson. We can't have it and it's really difficult for me.

Below is a description of an inspection visit of the school superintendent who expressed their surprise and disbelief concerning hospital teachers' conditions of work:

Our experience is that when inspectors, who visit us from time to time, come and see how we work, they always say: How can you work here like that? Running around with books on a trolley? Can you even have normal lessons here?

Another area teachers refer to is related to a lack of education for mainstream school teachers concerning students' chronic diseases $(\mathrm{F}=9)$. When talking about this problem, one of the participants gave an example of good practice, and talked about training that was organized by a hospital school for teachers from mainstream schools.

Our facility has organized such conferences several times. Teachers from mainstream schools from our region were invited. The seminars were conducted by our teachers, educators, or the headmaster. Also, several doctors from our hospital talked about the characteristics of diseases. So, there were two perspectives: doctors' perspective and teachers' perspective. I think these conferences have been probably the most effective way to share knowledge and give mainstream teachers a different view. It's been the best way to bring real results.

What's more, one of the participants suggests that the mainstream school could use the time of hospitalization to organize training for the teaching staff on the student's disease.

If there is a child at school with cystic fibrosis or type 1 diabetes, this kind of disease will stay with the kid for the rest of his life. When I'm talking about cooperation between schools, I mean that when the child is at the hospital, the mainstream school should prepare some educational activities about the disease or some training of the teaching staff and other school employees. 
Several interviewees highlight that the lack of knowledge about the disease the child is struggling with may result in the lack of understanding of the limitations the child encounters:

Mainstream school teachers often seem to be unaware of the emotional and physical consequences of a given illness that translates into certain child's behaviors. Then, they assess this child in a wrong way, completely unknowingly. And the child is then undeservedly, incorrectly assessed.

\subsection{Needs Connected with the Character of Work}

The next group of needs is connected with the characteristics of hospital teachers' work. Most often $(F=13)$, the participants expressed the need to adapt their teaching methods to an individual situation of a student and his/her health condition.

Often, children with chronic diseases, who may have some problems with learning, fall behind. At regular school, they cannot catch up, and here they can.

The worst thing is that mainstream school teachers don't understand that our work is fully individual. And a child who simply gets lost in a mass school, or is too stressed to attend lessons with thirty other children, in our school works one-to-one with the teacher and, as it has already been mentioned, can learn the material better than his peers from class, although our lessons are shorter.

The teachers also suggest that the therapeutic dimension of their work is important, and that it is often overlooked by some parties $(F=7)$. Therefore, it is important to highlight the non-didactic aspects of working with a student in a hospital school. One of the interviewed teachers draws attention to this aspect in the following way:

There is no social awareness of what therapeutic assessment is, why it is so important in our work, and how it supports our students. I think of supporting mental well-being, helping students to deal with stress, and providing them with means of articulating the stress they experience. We, educators, focus a lot on taking care of a child's well-being. We use educational and therapeutic content to support children's positive self-image, and help them develop talents and strengths. We often run workshops of all types, for example, art workshops, interactive workshops, where everybody has a chance to talk with each other, exchange views.

The participants also emphasize the need to recognize the normalizing function of the hospital school $(\mathrm{F}=6)$. They suggest that the hospital school helps children to ensure a sense of life continuity despite the change of environment, and experiencing stressful situations connected to hospitalization. The teachers perceive their role as being supportive to children and helping them to rebuild the lost sense of security. They underline this in their statements as follows:

For children school is an element of an ordinary, normal life.

It is important to explain to these parents and children what the hospital school is for and that it really helps to return to normality.

We are not here to tire the children up but to support them, especially in a situation, when their sense of security is in danger. And being in the role of a student really gives them stability and a sense of normalcy and continuity of life. 
An important element of hospital teachers' work is the need to be flexible and ready to work non-standard working hours $(\mathrm{F}=4)$ and teach lessons in combined classes $(\mathrm{F}=2)$. The teachers seem to experience constant changes they need to adapt to:

We have to adapt immediately to the situation of the moment.

I have to be extremely flexible. Because before I enter the hospital, I don't know who I will go to and what state the child will be in, with what willingness to learn, and with what skills.

Sometimes we have very little time to assess what the child needs most to make him feel comfortable in the hospital at a given moment.

Furthermore, the teachers emphasize that they need to adapt to working in different hospital wards, which often changes $(\mathrm{F}=4)$. When they work with students in oncology and psychiatric wards, they usually perceive their work as more challenging. Sometimes, teaching may be highly influenced by limitations of the disease (i.e., sudden deterioration in health, change of treatment that may have a negative impact on how the child feels). Teachers admit that they have to modify the predefined learning goals and adapt them to the current situation. Sometimes they have to stop their lessons $(F=2)$ because of medical procedures or deterioration of the student's condition.

\subsection{Psychological Needs}

In general, the participants perceive their work with children with chronic diseases as stressful. Sometimes, they experience difficult emotions and are not always able to easily deal with them. Several teachers expressed the need for stress management training $(\mathrm{F}=4)$. One of the teachers claims that workshops on coping with stress, training in establishing cooperation with parents and children, and training in helping those who lived through trauma (T18) could help teachers work more effectively.

As mentioned above, some of the interviewed teachers indicate that their work in a hospital school is saddled with a high level of stress. When asked for potential solutions, teachers suggested that social (emotional) support could be helpful $(\mathrm{F}=4)$. They admit that they should not burden family members and friends with work-related difficulties. Instead, they see the need for work supervision, which could take place in the form of group meetings. This idea is expressed in the following statement:

As teachers who work in hospitals, we should have support. I used to wonder about some supervision for teachers, similar to that the therapists and doctors in the psychiatric ward have.

Another area that the participants drew attention to is the need to cope with a student's death $(\mathrm{F}=6)$. Teachers describe such experiences as both harrowing, painful, and momentous.

The death of a child... All the children that I had a chance to meet and who passed away... I remember every child.

There are some work-related stressors ... It's really hard to cope with a student's death. Even after many, many years of work, it comes back, and it resides somewhere deep within. 


\subsection{Self-Fulfillment Needs Resulting from Job Satisfaction}

The need for self-fulfillment is analyzed in terms of job satisfaction. The most frequently mentioned source of teacher's satisfaction is good contact with students $(\mathrm{F}=13)$. Teachers also draw attention to the fact that students seek contact with them, want to participate in lessons despite their initial reluctance, and when they return to the hospital, they cannot wait to see the teachers. Sometimes children and adolescents also do not want to leave the hospital because they want to learn in the hospital school. The participants describe this area as follows:

It is really gratifying that these children are waiting for us and that they know that they can come to us and they will get help.

Once a student told me that he came to the hospital only because I was there.

Even a high school student sometimes says: I want to always stay in this school.

It's amazing that these kids wait for us, they don't want us to go. Sometimes our school is the only school they miss. In the beginning, we sometimes have to look for them because they hide in the toilets or under the bed. But once we gain their trust, we have them on our side. Then, it's they who start looking for us. I always say that at first, we're waiting for them, and then, they're waiting for us.

When the children came to say goodbye to me, they also said: We're going to pack you in our suitcase and take you to our town and our school.

I've seen children cry when they leave the hospital many times. They're leaving the hospital and they're crying-it's a bit strange, isn't it?.

Good contact with students is reflected in how they feel in the hospital school. When students smile and express joy $(\mathrm{F}=9)$, teachers feel that their work is important and gratifying:

From the very beginning, I feel really happy when students smile when they see me.

For me, it is satisfying that the child is smiling, happy, and joyful.

What is satisfying for me? A child's smile, which sometimes maybe is a bit weak because of all those medical procedures. And yet, when we give them hope, they smile.

An important aspect of teachers' work is students' engagement in school $(F=6)$. Teachers perceive it as a gratifying experience. They described situations in which children wanted to participate in lessons despite feeling unwell, for example after chemotherapy. Many teachers also feel satisfied when students achieve educational success $(F=5)$.

It's very important that children in our hospital school can be successful. With our help, thanks to less crowded lessons, we can devote more time to every child. We individualize our work, adapt it to the child's capabilities so that they can achieve success.

One of my students said to me that she had learned more in our school than in her mainstream school. 
Another important aspect of needs connected with teachers' self-fulfillment is parents' satisfaction $(\mathrm{F}=4)$ and students' gratitude $(\mathrm{F}=3)$.

Parents often tell us that they've learned something, for example, how to work with the child, what to pay attention to, and what they can work on with the kid.

\subsection{Needs Connected with Social Relationships}

The needs related to social relationships were analyzed in four dimensions: those with students, parents, hospital staff, and teachers from mainstream schools. Every dimension is described below in a separate subsection.

\subsubsection{Relationships with the Student}

Among important aspects of social relationships, teachers mention supporting students' well-being $(F=7)$ and improving contact with them $(F=6)$. They often keep children company and assist them in redefining their life goals and the ways to achieve them. One of the interviewees recalled the story of a student who had to give up his earlier life and sports career because of his illness. The teacher perceived her role as helping the child accept certain limitations, find new passions, build mental well-being, and strengthen self-esteem and resilience. Several teachers expressed similar opinions $(F=3)$.

Even if we know that the situation is difficult, we cannot cry over the children. We have to bring them a piece of the normal world, a normal conversation, sometimes connected with the school, sometimes related to something else important for the child.

The educator must keep children company and support them. I think this is another important role of the hospital school.

The teachers also suggest that it is important to support students' understanding of the difficulties resulting from the disease $(\mathrm{F}=3)$.

\subsubsection{Relationships with Parents}

The teachers also express the need to have good relationships with parents, establish good rapport and cooperation with them $(\mathrm{F}=12)$, and support them in difficult situations connected with the child's illness and hospitalization $(\mathrm{F}=7)$.

Our work as hospital teachers and educators also involves showing the parent what we do, and inviting them to work together, and this is sometimes a kind of springboard for them.

I always try to support a child's relatives who are at the hospital.

We support parents and our empathy, which is really necessary in our work, comes straight from the heart. It's not something that can be trained.

\subsubsection{Relationships with Hospital Staff (Doctors, Nurses)}

Another area is associated with hospital teachers' relationships with hospital staff. Many of the interviewed teachers think that doctors and nurses have difficulty in accepting and understanding the importance of their work as educators and facilitators. Sometimes they feel ignored and disregarded and they emphasize the need for recognition of their role $(\mathrm{F}=11)$. Moreover, one participant pointed out that if teachers' work was perceived as important, they would have better on-site facilities. Several teachers mention mutual 
respect as an important part of working in the same workplace $(F=4)$, especially as all parties need to share the same rooms.

I often feel pushed around, medical staff treat me like an object. They play down my role.

When the doctor said that children were there to get better, not to study, I said to him that a healthy child meant a healthy soma and psyche and that we should not forget about it.

I think that cooperation with a psychologist and an attending physician also plays a very important role. We should let medical staff know how much we value their work and that they should also appreciate our role in taking care of children's wellbeing.

If governments and hospital officials fully acknowledged that our work is needed and important, children and their parents would also know it. And if we are seen as dispensable, and that's what some people think, then we don't have enough space, dedicated rooms, or other resources. Sometimes you may get the impression that they expect us to be somewhere else.

\subsubsection{Relationships with Mainstream School Teachers}

Most participants highlight the importance of cooperation between the hospital school and mainstream schools. They express a strong need for mainstream school teachers to recognize grades they give in hospital schools $(\mathrm{F}=14)$. The teachers shared many similar stories about problems with grades that were called into question. As a result, students had to retake the tests they had already passed in the hospital school.

Regular schools do not accept the grades we give. It's a really big problem for us. They always have some objections and the headmaster of our school has to call them.

Our students work really hard. Sometimes we have a chemistry lesson, and there is a pump with chemo next to us. And then, the chemistry teacher from mainstream school does not want to accept the grades the student got. This is very upsetting for us.

Parents told me that teachers think of our grades as less important, they mark them as less valid and don't want to count them in. This is a huge problem, and nothing has changed for many years.

The parents often intervene and tell us that the mainstream school hasn't received the list of grades from our school. Of course, we always send them, sometimes more than once, but simply the teacher does not want to consider these grades. And then the battle begins between the hospital school and mainstream school. We try to convince them, but we really cannot do much about it. The mainstream school builds a wall between us. The parents come to us and ask: Why did you give those grades if they're irrelevant?

The mainstream school said they would not give her a school promotion certificate based on our grades because they disagree with them.

Many of the interviewed teachers perceive the cooperation between the hospital school and mainstream school as insufficient $(F=10)$. Another problem reported by several teachers is that sometimes teachers from the mainstream school do not keep any contact with the hospitalized student. According to several participants, teachers from mainstream 
schools should also keep in touch with the hospitalized child $(\mathrm{F}=4)$ and show interest in the student during his/her absence $(\mathrm{F}=3)$.

The teachers suggest that there is a need for a close liaison between both types of schools and that the exchange of information regarding students should be improved. Two teachers said that their work could be improved if mainstream school teachers provided information about the material recently learned in class $(\mathrm{F}=2)$.

The cooperation between schools also involves educating classmates about a chronic disease that the child has $(F=3)$. The participants see it as an opportunity to increase empathy among peers. However, it is necessary to respect the child and parents' individual decisions and ask for permission to talk about the disease in public. Sometimes, children may not want their classmates to know about the condition they have.

\section{Discussion}

The paper presents the results of qualitative research conducted among teachers from hospital schools as part of the international project Back to School. The qualitative data was obtained through group interviews. After coding the qualitative material, five main areas of needs emerged and they were analyzed in detail. In general, the results of the study correspond to the previous findings reported in other countries, which suggests that Polish hospital teachers work in a similar way to hospital teachers discussed in the literature. In telling their stories, the hospital teachers discussed the needs they have, resulting from their work with hospitalized children.

Learning in a hospital school has a positive effect on the hospitalized child [40], which is also a source of gratification for teachers. The results of the study suggest that teachers' needs for professional self-fulfillment are satisfied through contact with students and their parents [76]. The teachers emphasize that they appreciate the way children interact with them. Students often seek contact with teachers and express gratitude and enjoyment towards them. Another satisfying element is students' engagement in school despite difficult conditions. Children and adolescents benefit from hospital education not only because it helps them to minimize the risk of falling behind with school material, but also because it is a source of normalcy in their hospital life [32,59]. Contact with teachers and focusing on things other than hospitalization reduces students' anxiety and gives them a sense of life continuation [82]. In general, teachers' role in supporting students with chronic diseases and their parents is a source of satisfaction and motivation for them [83,84].

Another important area that emerged in the interviews is connected with fears of the marginalization of hospital schools' role. There seems to be a tendency to close those schools to optimize local governments' budgets. In addition, some teachers feel neglected as a professional group on the national level. They recalled a situation when the government introduced school regulations due to COVID-19 in March 2020. However, hospital schools were omitted in the official documents. Only after 30 days was another regulation concerning hospital schools introduced. Moreover, in the Report on Education in Special Schools by the Polish Supreme Audit Office [85], there is no information about the number of hospital schools or their funding. However, such data about other types of school are included. Therefore, it is difficult to find reliable information on the subject of hospital education. Poland is not alone in this, however. Similar problems were encountered by researchers from Canada, who concluded that information on hospital schools was not readily available and the hospital schools seemed neglected [86]. The problem of lack of information about hospital schools was also reported, for example, by the House of Commons Education Committee in England in their report on special education [87]. Hospital teachers often feel neglected and their perception of organizational support seems low, which can have a negative impact on their overall job satisfaction and, in turn, on their efficacy [88].

The research results suggest that dedicated school rooms are an important element of hospital school infrastructure from the perspective of teachers. However, they are scarce in hospitals. Insufficient on-site facilities and the lack of school rooms were often indicated by 
the interviewees as significant problems. Hospital teachers usually teach at the bedside [62] or in recreational rooms, where patients also spend their free time, play games, and hang out with friends. Education in a hospital is individualized, and teachers organize oneto-one lessons and adopt a highly flexible, child-centered approach because it is more effective and adequate in a hospital setting $[69,73,89]$. However, to have a successful lesson, the teacher and the student also need to have a quiet and calm place to work. Children who do not have such a learning environment may find it difficult to focus on the school material $[90,91]$. Similar findings have been reported by other studies who highlight the hospital teachers' need for more convenient working conditions [59,92]. In contrast, school rooms are widely available in German hospital schools, for example [60].

One of the most important needs mentioned by the interviewees is communication and cooperation with mainstream schools. There are no systemic solutions for passing information between schools in Poland, and this responsibility is often handed over to parents. The interviewed teachers indicate that there is a need for better communication and information sharing. Attaching value to this type of contact between schools is consistent with other studies $[39,69,73,89,93]$. For example, in Ireland, teachers from both types of schools have access to a password-protected database that contains students' personal details and allows them to exchange information. The database has information about the class level, individual educational plan, material that has been covered in mainstream and hospital schools, and general information about the hospital stay [69]. Further research on communication between hospital school teachers and mainstream school teachers in the Polish context is needed, preferably with both parties involved.

Another area of needs highlighted by the interviewed teachers is for cooperation and information exchange between them and medical staff. It is important because the medical condition of a patient-student can temporarily harm his or her ability to learn. In Germany, for example, it has been reported that teachers can take part in special rounds along with "psychologists, physiotherapists, nurses, and pediatricians concentrating on individual patients" [60]. Similarly, in Ireland, there are "weekly psychosocial multidisciplinary meetings" [60] that facilitate the exchange of information, discussion of specific cases, and integration of hospital school teams. This sort of cooperation has been assessed to be of "paramount importance" for Irish teachers [69]. Such solutions could be helpful for other teachers as well.

The study shows that hospital personnel's attitude towards the teachers' role is important. Hospital teachers need to feel valued by other hospital workers, and they believe their work is important for children. The main purpose of a child's stay in the hospital is treatment. However, teachers also point out that taking care of students' mental health should not be overlooked. Teachers and educators support children and take care of their mental well-being [41]. Hospital schools are not only about learning but are also a springboard for children [94]. Teachers organize various activities, thanks to which children can spend time together creatively and socialize [41], which gives them a sense of normalcy in their hospital life [45]. Unfortunately, our study suggests that generally, from the teachers' perspective, the majority of medical personnel seem to downplay the role of teachers. Similar findings were reported by Der-Fang Chen et al., who conducted interviews with medical personnel and social workers working in 29 pediatric hospitals that scored excellent for the quality of care. It turned out that "none of the social workers/nurses from (...) 28 'excellent' hospitals described the importance of or need for education" at the hospital setting [95]. Other studies on hospital teachers' work have also revealed that one of the biggest sources of hospital teachers' professional dissatisfaction is poor communication with medical personnel and lack of recognition from them $[16,59,94]$.

Some participants of the study report that stressful and emotionally challenging situations are part of working in the hospital. However, they do not receive any professional psychological support. It is important because teachers sometimes experience students' physical and mental breakdowns and death $[16,45,59,96,97]$. Additionally, they are often a source of support for children with chronic diseases and their parents in difficult and 
stressful situations [59,92]. Because of their close contact with children, they tend to get emotionally involved in their work, and their professional attitude combined with working under stress may be an additional psychological burden for them [59,92,97,98]. Several teachers in the study expressed the need for some help in dealing with work-related stress. For example, they suggested that they could have counseling or support groups. In an Irish study, Kahleen states that "data sets reflect an overwhelming consensus that the emotional aspect of working as a hospital teacher is the biggest challenge faced when working in a hospital setting" [69] (p.52). The research has shown that teachers' emotional exhaustion, which is likely to occur under long-term stress, has a negative influence on students' learning [99] and poses a risk for burnout [100]. In light of these findings, it is clear that there is a dire need to provide hospital teachers with professional psychological support. An example of good practice can be found in Ireland, where teachers have weekly debriefing sessions and supervision to discuss concerns and difficulties [69].

The strongest side of the study is that it draws attention to hospital teachers' needs, and potentially addressing them with solutions and support may improve how children and adolescents function during hospitalization $[16,88]$. It has been shown that when teachers' needs are satisfied, their ability to take care of students' well-being increases [101]. Another important advantage of the study is that the majority of participants had extensive professional experience. Many years of professional practice as a hospital school teacher means that the obtained results are significant in terms of rich experience. Further, an important asset of the study is the diversity of the studied group. Some participants worked with students at different educational stages and taught different subjects, and others were involved in organizing extracurricular activities. The diversity made it possible to obtain a more detailed picture of the characteristics of a hospital teacher's work. It is also valuable that some teachers from health care resort schools took part in the interviews because their workflow is different than in hospital-based schools.

One significant finding from this study, which has not been previously reported, is that mainstream school teachers seem to perceive grades given by hospital teachers as inferior, far-fetched, and not equivalent to the grades given in class. For some reason, mainstream school teachers often do not want to accept grades from hospital schools. It is worth mentioning that in Poland, hospital teachers assess students according to the in-school grading system, follow the core curriculum, and are qualified education employees. It has been shown that the openness of mainstream schools, willingness to cooperate, and teachers' knowledge of chronic diseases generally improve the child's well-being and education $[14,102]$.

The study had several limitations. Among the factors that limited the research most was the outbreak of the SARS-CoV-2 pandemic and the restrictions introduced throughout the country. The study was planned before the pandemic so it was necessary to adapt the schedule to the changing situation. The restrictions on educational institutions (online learning and blended learning) and restrictions on hospitals (no visits, limitations of the number of people staying in hospital wards) hindered establishing good rapport with hospital schools and the teachers. Another limitation was the way interviews were conducted. Online interviews required additional equipment and posed potential difficulties of a technical nature. Another potential limitation was the location of the interviews. The researchers did not have any influence on the place where the participants stayed during the interviews and they could not provide a place that would allow teachers to fully focus on the interview. What's more, one of the limitations of the study is the uneven distribution of gender in the study group. Women were predominant (19), and only two men took part in the interviews. This could also be caused by the aforementioned limitations related to the pandemic situation. In addition, the study was focused entirely on the Polish context, and the results should not be generalized to other countries. Because of the qualitative nature of the study, the conclusions should also not be generalized to the entire population of hospital teachers. However, the study can be used as a basis for further investigation i.e., in quantitative research on a larger scale. 


\section{Conclusions}

Hospital teachers play an important role in keeping children with diseases engaged in education [103]. Apart from pursuing educational goals, teachers also pay attention to the normalizing function of hospital schools and take care of children's well-being. They are qualified employees who are aware that hospital education is of vital importance to students with chronic diseases [104], and that attending hospital school is their stepping stone to achieving sound mental health.

One of the conclusions from the research is that some hospital teachers seem to be afraid of school marginalization due to funding cuts. They feel that they are a systematically neglected group without systemic mental health support, with no widespread stress management courses, and no dedicated school rooms. Another conclusion is that teachers need their work to be validated by the mainstream school and hospital personnel. The interviewees pointed to the problem of downgrading the importance of education in hospital schools, which is a source of dissatisfaction for the teachers. Although hospital schools appear to be well integrated into the hospital environment, many teachers feel that their role is underestimated and undervalued by medical staff. The lack of recognition can result in feeling dispensable, which in turn can cause frustration and decreased motivation [59].

Hospital teachers' and sanatorium teachers' work is important. By teaching children and adolescents who experience different crises, they contribute to restoring their stable functioning. Hospital teachers' work satisfaction seems important to the high quality of teaching and care. Therefore, it is important to address teachers' needs for recognition from mainstream school teachers, medical staff, and government officials. There seems to be a need for spreading awareness of the importance of schools in health care institutions.

Author Contributions: Conceptualization, A.M.-S., A.B., and M.G.; Data curation, A.B. and M.G.; Formal analysis, M.G. and A.M.-S.; Funding acquisition, A.M.-S. and D.K.; Investigation, A.M.-S. and A.B.; Methodology, A.M.-S., A.B., and M.G.; Project administration A.M.-S. and M.G., Supervision D.K.; Validation M.G., Visualization, A.B. and M.G.; Writing-original draft preparation, A.M.-S. and A.B.; Writing-review and editing, M.G. and D.K. All authors have read and agreed to the published version of the manuscript.

Funding: This research was funded by the Back to School Project, ERASMUS+, grant number 2019-1-PL01-KA201-065602.

Institutional Review Board Statement: The BTS Project received a positive opinion from the Bioethical Committee of the Institute of Mother and Child (number 23/2020, 21 May 2020).

Informed Consent Statement: Informed consent was obtained from all subjects involved in the study.

Data Availability Statement: The results can be found at the Back to School Project's coordinator.

Acknowledgments: The authors would like to thank all the heads and teachers from hospital schools who took part in the study.

Conflicts of Interest: The authors declare no conflict of interest.

\section{References}

1. Shaw, S.R.; McCabe, P.C. Hospital-to-School Transition for Children with Chronic Illness: Meeting the New Challenges of an Evolving Health Care System. Psychol. Schs. 2008, 45, 74-87. [CrossRef]

2. Central Statistical Office. Health Status of Population in Poland in 2014; Social Surveys and Living Conditions Department: Warsaw, Poland, 2016.

3. Sawyer, S.M.; Drew, S.; Yeo, M.S.; Britto, M.T. Adolescents with a Chronic Condition: Challenges Living, Challenges Treating. Lancet 2007, 369, 1481-1489. [CrossRef]

4. World Health Organization. Tackling Chronic Disease in Europe: Strategies, Interventions and Challenges; WHO: Geneva, Switzerland, 2010.

5. Gore, F.M.; Bloem, P.J.N.; Patton, G.C.; Ferguson, J.; Joseph, V.; Coffey, C.; Sawyer, S.M.; Mathers, C.D. Global Burden of Disease in Young People Aged 10-24 Years: A Systematic Analysis. Lancet 2011, 377, 2093-2102. [CrossRef]

6. World Health Organization. Preventing Chronic Diseases: A Vital Investment; WHO: Geneva, Switzerland, 2005.

7. Perrin, J.M.; Anderson, L.E.; Van Cleave, J. The Rise In Chronic Conditions Among Infants, Children, And Youth Can Be Met With Continued Health System Innovations. Health Aff. 2014, 33, 2099-2105. [CrossRef] [PubMed] 
8. Van Cleave, J. Dynamics of Obesity and Chronic Health Conditions Among Children and Youth. JAMA 2010, 303, 623-630. [CrossRef] [PubMed]

9. Brennan, P.; Perola, M.; van Ommen, G.-J.; Riboli, E. Chronic Disease Research in Europe and the Need for Integrated Population Cohorts. Eur. J. Epidemiol. 2017, 32, 741-749. [CrossRef] [PubMed]

10. O'Donohue, W.T. Behavioral Approaches to Chronic Disease in Adolescence: A Guide to Integrative Care; Springer: New York, NY, USA, 2009; ISBN 9780387876863.

11. Santos, T.; de Matos, M.G.; Marques, A.; Simões, C.; Leal, I.; Machado, M.C. Psychosocial Profile in Portuguese Adolescents with Chronic Disease Attending an Outpatient Department in a Hospital Setting. Int. J. Pediatrics 2018, 2018, 9382648. [CrossRef] [PubMed]

12. Rokach, A. Psychological, Emotional and Physical Experiences of Hospitalized Children. Clin. Case Rep. Rev. 2016, 2, 399-401. [CrossRef]

13. Crump, C.; Rivera, D.; London, R.; Landau, M.; Erlendson, B.; Rodriguez, E. Chronic Health Conditions and School Performance among Children and Youth. Ann. Epidemiol. 2013, 23, 179-184. [CrossRef]

14. Thompson, A.L.; Christiansen, H.L.; Elam, M.; Hoag, J.; Irwin, M.K.; Pao, M.; Voll, M.; Noll, R.B.; Kelly, K.P. Academic Continuity and School Reentry Support as a Standard of Care in Pediatric Oncology: School Reentry in Pediatric Oncology. Pediatr. Blood Cancer 2015, 62, 805-817. [CrossRef]

15. Lipstein, E.A.; Perrin, J.M.; Kuhlthau, K.A. School Absenteeism, Health Status, and Health Care Utilization among Children with Asthma: Associations with Parental Chronic Disease. Pediatrics 2009, 123, e60-e66. [CrossRef] [PubMed]

16. Steinke, S.M.; Elam, M.; Irwin, M.K.; Sexton, K.; McGraw, A. Pediatric Hospital School Programming: An Examination of Educational Services for Students Who Are Hospitalized. Phys. Disabil. Educ. Relat. Serv. 2016, 35, 28-45. [CrossRef]

17. Mombaers, T.; Donche, V. Hospital School Students' Academic Motivation and Support Needs: A Self-Determination Perspective. Front. Educ. 2020, 5, 106. [CrossRef]

18. Allen, C.; Diamond-Myrsten, S.; Rollins, L. School Absenteeism in Children and Adolescents. Am. Fam. Physician 2018, 98, 738-744. [PubMed]

19. Liu, J.; Lee, M.; Gershenson, S. The Short- and Long-Run Impacts of Secondary Student Absences. J. Public Econ. 2019, $199,104441$. [CrossRef]

20. Santibañez, L.; Guarino, C.M. The Effects of Absenteeism on Academic and Social-Emotional Outcomes: Lessons for COVID-19. Educ. Res. 2021, 0013189X2199448. [CrossRef]

21. Gottfried, M.A. Chronic Absenteeism in the Classroom Context: Effects on Achievement. Urban Educ. 2019, 54, 3-34. [CrossRef]

22. Bsiri-Moghaddam, K.; Basiri-Moghaddam, M.; Sadeghmoghaddam, L.; Ahmadi, F. The Concept of Hospitalization of Children from the Viewpoint of Parents and Children. Iran. J. Pediatrics 2011, 2, 201-208.

23. Sheinfeld Gorin, S.; McAuliffe, P. Implications of Childhood Cancer Survivors in the Classroom and the School. Health Educ. 2009, 109, 25-48. [CrossRef]

24. Jackson, M. The Special Educational Needs of Adolescents Living with Chronic Illness: A Literature Review. Int. J. Incl. Educ. 2013, 17, 543-554. [CrossRef]

25. Noonan, K.; Reichman, N.E.; Corman, H.; Jiménez, M.E. School and Community Involvement of Adolescents with Chronic Health Conditions. J. Adolesc. Health 2020, 67, 576-582. [CrossRef] [PubMed]

26. Allison, M.A.; Attisha, E. The Link between School Attendance and Good Health. Pediatrics 2019, 143. [CrossRef]

27. Yeo, M.; Sawyer, S. Chronic Illness and Disability. BMJ 2005, 330, 721-723. [CrossRef]

28. Delvecchio, E.; Salcuni, S.; Lis, A.; Germani, A.; Di Riso, D. Hospitalized Children: Anxiety, Coping Strategies, and Pretend Play. Front. Public Health. 2019, 7, 250. [CrossRef]

29. González-Gil, F.; Jenaro, C.; Gómez-Vela, M.; Flores, N. Perceived Quality of Life and Health of Hospitalized Children. Child Ind. Res. 2008, 1, 198-209. [CrossRef]

30. Hostert, P.C.D.C.P.; Motta, A.B.; Enumo, S.R.F. Coping with Hospitalization in Children with Cancer: The Importance of the Hospital School. Estud. Psicol. 2015, 32, 627-639. [CrossRef]

31. Crosby, L.E.; Joffe, N.E.; Irwin, M.K.; Strong, H.; Peugh, J.; Shook, L.; Kalinyak, K.A.; Mitchell, M.J. School Performance and Disease Interference in Adolescents with Sickle Cell Disease. Phys. Disabil. Educ. Relat. Serv. 2015, 34, 14-30. [CrossRef] [PubMed]

32. Weiss, C.L.; Blizzard, A.M.; Vaughan, C.; Sydnor-Diggs, T.; Edwards, S.; Stephan, S.H. Supporting the Transition from Inpatient Hospitalization to School. Child Adolesc. Psychiatr. Clin. N. Am. 2015, 24, 371-383. [CrossRef]

33. Tremolada, M.; Taverna, L.; Bonichini, S.; Pillon, M.; Biffi, A.; Putti, M.C. Pediatric Patients Treated for Leukemia Back to School: A Mixed-Method Analysis of Narratives about Daily Life and Illness Experience. Behav. Sci. 2020, 10, 107. [CrossRef]

34. Coyne, I. Children's Experiences of Hospitalization. J. Child Health Care. 2006, 10, 326-336. [CrossRef] [PubMed]

35. Wilson, M.E.; Megel, M.E.; Enenbach, L.; Carlson, K.L. The Voices of Children: Stories About Hospitalization. J. Pediatric Health Care 2010, 24, 95-102. [CrossRef] [PubMed]

36. Fletcher, T.; Glasper, A.; Prudhoe, G.; Battrick, C.; Coles, L.; Weaver, K.; Ireland, L. Building the Future: Children's Views on Nurses and Hospital Care. Br. J. Nurs. 2011, 20, 39-45. [CrossRef]

37. Livesley, J.; Long, T. Children's Experiences as Hospital In-Patients: Voice, Competence and Work. Messages for Nursing from a Critical Ethnographic Study. Int. J. Nurs. Stud. 2013, 50, 1292-1303. [CrossRef] [PubMed] 
38. Reyhani, T.; Aemmi, S.; Emami Zeydi, A. The Effect of Teacher's Presence at Children's Bedside on the Anxiety of Mothers with Hospitalized Children: A Randomized Clinical Trial. Iran. J. Nurs. Midwifery Res. 2016, 21, 436. [CrossRef] [PubMed]

39. Fuengfoo, A.; Leelathanaporn, S.; Mekrungcharas, T.; Sakulnoom, K.; Owjinda, S.; Noipong, P.; Srinuan, S.; Kumjaroen, S.; Phonok, N. Effectiveness of the Hospital Learning Center (Queen Sirikit National Institute of Child Health): Satisfaction with Service and Parents' Attitudes towards Children's Illness. F1000Res. 2019, 8, 1616. [CrossRef] [PubMed]

40. Filipušić, I.; Opić, S.; Krešić, V. Some Specificities of Students' Satisfaction with Hospital School. Croat. J. Educ. 2015, 17, 97-111.

41. Guleryuz, O.D.; Hasirci, D. Children's Hospital Schools as Social Environments: A Turkish Example. Proceeding of the INTED2018, Valencia, Spain, 5-7 March 2018; pp. 4845-4854.

42. Iwu, C.; Ezeuduji, I.; Iwu, I.; Ikebuaku, K.; Tengeh, R. Achieving Quality Education by Understanding Teacher Job Satisfaction Determinants. Soc. Sci. 2018, 7, 25. [CrossRef]

43. Toropova, A.; Myrberg, E.; Johansson, S. Teacher Job Satisfaction: The Importance of School Working Conditions and Teacher Characteristics. Educ. Rev. 2021, 73, 71-97. [CrossRef]

44. Peršēvica, A. The Significance of the Teachers Job Satisfaction in the Process of Assuring Quality Education. Probl. Educ. 21th Century 2011, 34, 98-109.

45. Lemke, R.E. A Hospital School: An Intrinsic Case Study; North Carolina State University: Raleigh, NC, USA, 2004.

46. Abós, Á.; Haerens, L.; Sevil, J.; Aelterman, N.; García-González, L. Teachers' Motivation in Relation to Their Psychological Functioning and Interpersonal Style: A Variable- and Person-Centered Approach. Teach. Teach. Educ. 2018, 74, 21-34. [CrossRef]

47. Ololube, N.P. Teachers Job Satisfaction and Motivation for School Effectiveness: An Assessment. Essays Educ. $2006,18,60-87$.

48. Sisask, M.; Värnik, P.; Värnik, A.; Apter, A.; Balazs, J.; Balint, M.; Bobes, J.; Brunner, R.; Corcoran, P.; Cosman, D.; et al. Teacher Satisfaction with School and Psychological Well-Being Affects Their Readiness to Help Children with Mental Health Problems. Health Educ. J. 2014, 73, 382-393. [CrossRef]

49. Watt, H.M.G.; Richardson, P.W. Motivations, Perceptions, and Aspirations Concerning Teaching as a Career for Different Types of Beginning Teachers. Learn. Instr. 2008, 18, 408-428. [CrossRef]

50. Jiménez, N.N.V.; Montes, J.E.O.; Alcocer, E.C.P. Hospital Pedagogy: A Space of Love and Recognition for the Oncological Pediatric Patient. Texto Contexto-Enferm. 2019, 28. [CrossRef]

51. Curtis Museum. The Lord Mayor Treloar Hospital and College; Hampshire Cultural Trust: London, UK, 2019.

52. Learning at Home and in the Hospital. In The Institutional Environments of Home and Hospital Education (HHE) in Europe; LeHo: Guangdong, China, 2015.

53. The Ministry of National Education. Regulation of the Minister of National Education of 8 March 2013 on the Organization of Education, and Forms of Special Care and Educational Activities in Kindergartens, Special Schools, Social Welfare Units, and Schools Organized in Medical Entities; Polish Government: Warsaw, Poland, 2013.

54. The Ministry of National Education. Regulation of the Minister of National Education of 5 February 2020 Changing the Previous Regulation of Organization of Education, and Forms of Special Care and Educational Activities in Kindergartens, Special Schools, Social Welfare Units, and Schools Organized in Medical Entities; Polish Government: Warsaw, Poland, 2020.

55. The Ministry of National Education. Regulation of the Minister of National Education of 24 August 2017 on the Organization of Education, and Forms of Special Care and Educational Activities in Kindergartens, Special Schools, Social Welfare Units, and Schools Organized in Medical Entities; Polish Government: Warsaw, Poland, 2017.

56. The Ministry of National Education. Regulation of the Minister of National Education of 13 August 2019 Changing the Previous Regulation of Organization of Education, and Forms of Special Care and Educational Activities in Kindergartens, Special Schools, Social Welfare Units, and Schools Organized in Medical Entities; Polish Government: Warsaw, Poland, 2019.

57. Hardy, M. These Soviet-Era Spas Are Still Accepting Guests. WIRED. Available online: https://www.wired.com/story/sovietera-spa-gallery/ (accessed on 21 May 2021).

58. Gutenbrunner, C.; Bender, T.; Cantista, P.; Karagülle, Z. A Proposal for a Worldwide Definition of Health Resort Medicine, Balneology, Medical Hydrology and Climatology. Int. J. Biometeorol. 2010, 54, 495-507. [CrossRef] [PubMed]

59. Benigno, V.; Fante, C. Hospital School Teachers' Sense of Stress and Gratification: An Investigation of the Italian Context. Contin. Educ. 2020, 1, 37. [CrossRef]

60. Ehrich, J.; Grote, U.; Gerber-Grote, A.; Strassburg, M. The Child Health Care System of Germany. J. Pediatrics 2016, 177, S71-S86. [CrossRef] [PubMed]

61. Behr, J. The Right to Education in Healthcare Entities. The Analysis Based on Public Primary Special Schools. Folia Iurid. Univ. Wratislav. 2016, 5, 165-180.

62. Altariva, S.; Carmody, P.; Evans, A.; Evans, M.; Osman, K.; Smith, C. Education Alternatives; AGCAS: Sheffield, South Yorkshire, 2007.

63. Mintz, J.; Palaiologou, I.; Carroll, C. A Review of Educational Provision for Children Unable to Attend School for Medical Reasons; University College London: London, UK, 2018.

64. Tsokova, D.; Halilović, M. Current Developments with Inclusive Education Policy and Practice in Bulgaria and Bosnia and Herzegovina. Hung. Educ. Res. J. 2015, 5, 1-17.

65. Csinády, R.V. Hospital Pedagogy, a Bridge between Hospital and School. Herj Hung. Educ. Res. J. 2015, 5, 49-65.

66. Birch, J.; Curtis, P.; James, A. Sense and Sensibilities: In Search of the Child-Friendly Hospital. Built Env. 2007, 33, 405-416. [CrossRef] 
67. Lambert, V.; Coad, J.; Hicks, P.; Glacken, M. Social Spaces for Young Children in Hospital: Social Spaces Children in Hospital. Child Care Health Dev. 2014, 40, 195-204. [CrossRef]

68. World Health Organization. Creating an Environment for Emotional and Social Well-Being: An Important Responsibility of a Health Promoting and Child-Friendly School; WHO: Geneva, Switzerland, 2003.

69. Keehan, S. Continuing Education in Irish Hospital Schools: Provision for and Challenges for Teachers. Contin. Educ. 2021, 2, 42. [CrossRef]

70. Mourik, O. Professional Profile for Hospital Teachers; ZIEZON: Hague, The Netherlands, 2008.

71. Wilkie, K.J. 'Absence Makes the Heart Grow Fonder': Students with Chronic Illness Seeking Academic Continuity through Interaction with Their Teachers at School. Australas. J. Spec. Educ. 2012, 36, 1-20. [CrossRef]

72. Llywodraeth Cymru Welsh Government. Supporting Learners with Healthcare Needs; Welsh Government: Cardiff, Wales, 2017.

73. Maher, D.; Perry, R.; Curry, J.; Johnston, R. Perceptions of the Hospital School Experience: Exploring Transition, Spaces for Engagement and Technology. Int. J. Adultcommunity Prof. Learn. 2014, 20, 9-21.

74. The Royal Children's Hospital Education Institute. Innovative Learning Environments (ILE). In Inventory Case Study: The Royal Children's Hospital; CERI: Melbourne, Australian, 2012.

75. Irwin, M.K.; Elam, M. Are We Leaving Children with Chronic Illness Behind? Phys. Disabil. Educ. Relat. Serv. 2011, 30, 67-80.

76. João, V.; Saul Neves, D.J.; Claudia, R.; José, M.C. Teacher Motivation, Work Satisfaction, and Positive Psychological Capital: A Literature Review. EJREP 2016, 14, 439-461. [CrossRef]

77. Adams, W.C. Conducting Semi-Structured Interviews. In Handbook of Practical Program Evaluation; Newcomer, K.E., Hatry, H.P., Wholey, J.S., Eds.; John Wiley \& Sons, Inc.: Hoboken, NJ, USA, 2015; pp. 492-505. ISBN 9781119171386.

78. Kvale, S. Doing Interviews; SAGE: Thousand Oaks, CA, USA, 2008; ISBN 9781446226834.

79. Almeida, E.; Rosero, A.; Chiluiza, W.; Castillo, D. Reflections on Qualitative Research in Education. Rev. Cognosis Rev. Filos. Let. Cienc. Educ. 2021, VI, 101-118.

80. Education Information System. In List of Schools and Educational Institutions; Official Website of the Republic of Poland: Warsaw, Poland, 2019.

81. Blandford, A.E. Semi-structured Qualitative Studies. In The Encyclopedia of Human-Computer Interaction; Soegaard, M., Dam, R., Eds.; Interaction Design Foundation: Aarhus, Denmark, 2013.

82. Ferrara, L.; Flammia, A. The Hospital School towards an Integrated Model of Training of Quality. Am. J. Educ. Res. 2013, 1, 442-448. [CrossRef]

83. Adams, K.S.; Christenson, S.L. Trust and the Family-School Relationship Examination of Parent-Teacher Differences in Elementary and Secondary Grades. J. Sch. Psychol. 2000, 38, 477-497. [CrossRef]

84. Lopez, C.; Corcoran, T. Relationships with Special Needs Students: Exploring Primary Teachers' Descriptions. Int. J. Incl. Educ. 2014, 18, 1304-1320. [CrossRef]

85. Polish Supreme Audit Office. Report on Education in Special Schools; Polish Department of Science, Education and National Heritage: Warsaw, Poland, 2020.

86. Ratnapalan, S.; Rayar, M.S.; Crawley, M. Educational Services for Hospitalized Children. Paediatr. Child Health 2009, 14, 433-436. [CrossRef]

87. House of Commons Education Committee. Special Educational Needs and Disabilities: Government Response to the Committee's First Report of Session 2019; House of Commons: London, UK, 2019.

88. Edinger, S.K.; Edinger, M.J. Improving Teacher Job Satisfaction: The Roles of Social Capital, Teacher Efficacy, and Support. J. Psychol. 2018, 152, 573-593. [CrossRef]

89. Äärelä, T.; Määttä, K.; Uusiautti, S. The Challenges of Parent-Teacher Collaboration in the Light of Hospital School Pedagogy. Early Child Dev. Care 2018, 188, 709-722. [CrossRef]

90. Woolner, P.; Hall, E. Noise in Schools: A Holistic Approach to the Issue. Int. J. Env. Res. Public Health 2010, 7, 3255-3269. [CrossRef] [PubMed]

91. Postholm, M.B. Classroom Management: What Does Research Tell Us? Eur. Educ. Res. J. 2013, 12, 389-402. [CrossRef]

92. Iş1ktekiner, F.S.; Altun, S. Problems and Issues at Hospital Schools. Educ. Sci. 2011, 36, 318-331.

93. Todis, B.; McCart, M.; Glang, A. Hospital to School Transition Following Traumatic Brain Injury: A Qualitative Longitudinal Study. NeuroRehabilitation 2018, 42, 269-276. [CrossRef]

94. Wilks, S.A. Charter for Children's Learning at the Royal Children's Hospital: Literature Review; The University of Melbourne: Melbourne, Australia, 2010.

95. Chen, D.-F.; Tsai, T.-C.; Su, Y.-T.; Lin, C.-W. Hospital-Based School for Children with Chronic Illness in Taiwan. J. Formos. Med. Assoc. 2015, 114, 995-999. [CrossRef] [PubMed]

96. West, A.M.; Denzer, A.Q.; Wildman, B.G.; Anhalt, K. Teacher Perception of Burden and Willingness to Accommodate Children with Chronic Health Conditions. Adv. Sch. Ment. Health Promot. 2013, 6, 35-50. [CrossRef]

97. Hart, L.; Garza, Y. Teachers Perceptions of Effects of a Student's Death: A Phenomenological Study. Omega 2013, 66, 301-311. [CrossRef] [PubMed]

98. Kaplan, E. Teaching Your Heart Out: Emotional Labor and the Need for Systemic Change. Edutopia. Available online: https: //www.edutopia.org/article/teaching-your-heart-out-emotional-labor-and-need-systemic-change (accessed on 21 May 2021). 
99. Klusmann, U.; Richter, D.; Lüdtke, O. Teachers' Emotional Exhaustion Is Negatively Related to Students' Achievement: Evidence from a Large-Scale Assessment Study. J. Educ. Psychol. 2016, 108, 1193-1203. [CrossRef]

100. Herman, K.C.; Hickmon-Rosa, J.; Reinke, W.M. Empirically Derived Profiles of Teacher Stress, Burnout, Self-Efficacy, and Coping and Associated Student Outcomes. J. Posit. Behav. Interv. 2018, 20, 90-100. [CrossRef]

101. Elek, C.; Quach, J.; Moore, T.; West, S.; Goldfeld, S.; Symes, L.; Oberklaid, F. Supporting Teachers, Supporting Children: Teacher Professional Development Needs at the Health-Education Interface; Murdoch Childrens Research Institute: Parkville, Australia; The Royal Children's Hospital Centre for Community Child Health: Melbourne, Australia, 2017.

102. Hinton, D.; Kirk, S. Teachers' Perspectives of Supporting Pupils with Long-Term Health Conditions in Mainstream Schools: A Narrative Review of the Literature. Health Soc. Care Community 2015, 23, 107-120. [CrossRef] [PubMed]

103. Hopkins, L.; Green, J.; Henry, J.; Edwards, B.; Wong, S. Staying Engaged: The Role of Teachers and Schools in Keeping Young People with Health Conditions Engaged in Education. Aust. Educ. Res. 2014, 41, 25-41. [CrossRef]

104. Leger, P. Practice of Supporting Young People with Chronic Health Conditions in Hospital and Schools. Int. J. Incl. Educ. 2014, 18, 253-269. [CrossRef] 